\title{
Fiqh review on zakah of marine resources
}

\author{
Hafiz Mubarraq Haridhi ${ }^{1}$ and Fikriah Fikriah ${ }^{2 *}$ \\ ${ }^{1}$ Department of Islamic Economic, Faculty of Economic and Business, Universitas Syiah Kuala, Banda Aceh 23111, Indonesia. \\ ${ }^{2}$ Department of Economic Development, Faculty of Economic and Business, Universitas Syiah Kuala, Banda Aceh 23111, \\ Indonesia.
}

\begin{abstract}
The obligation of zakah for Muslims is imposed on valuable assets and it reaches the nishab level. The objectives of the shari'ah of zakah are to create an even distribution of income, avoid social inequality and raise the standard of living of the poor. Every asset that is obtained by a human being in the form of findings, results of efforts, work, gifts, and others that is fully owned, by achieving the nishab, must be paid its zakah. In classical fiqh, the classification of zakah maal is still limited, so that scholars continue to develop its classification with various legal istinbath methods. Zakah on marine resources also raises interpretations among scholars so that it needs to be studied from a fiqh perspective. Marine resources, both valuable goods and fisheries in large quantities which are used as sources of income and reach the nishab, need to be reviewed for its zakah regulation. This study is a literature review that reviews classical to modern zakah figh. This normative research found that marine resources that reach the nishab must be taken out as zakah for agriculture, commerce, mining, and others. Differences of opinion among scholars in arguing whether or not zakah on the sea resources is obligatory are based on the presence or absence of sources of livelihood from marine products at that time, so that differences in times led to differences of opinion. However, marine resources today have become a big source of livelihood for certain people. So that all forms of income that reach the nishab must be issued zakah. It can be concluded, that the zakah level of the traded marine products can be verified to commercial zakah or gold and silver zakah, which is $2.5 \%$, or zakah on findings, which is between $2.5 \%$ and $20 \%$, it depending on the type of resources obtained.
\end{abstract}

\section{Introduction}

The word of Maal comes from arabic 'mala' which means leaning or turning from the middle to one side, and al-maal is defined as everything that pleases humans and they maintain, both in the form of material and in the form of benefits [1]. The attitude towards wealth should not be excessive because humans are only a temporary given amanah. Allah tests people with wealth and gives pleasure from it, one of which is also to achieve falah and hayatan tayyibah. Both of these can be realized through the fulfillment of the objectives of the Shari'a. Imam Ghazali includes cases that can protect religion, soul, mind, lineage and wealthy into maqasid [2]. Among the forms of protection of property is to clean it through the payment of zakat, because on every wealth that reaches the nisab, there are few other people's rights. So that zakat is also a maqashid of wealth protection.

The scholars of Fiqh differ on the ruling on items that are explored from marine. Marine products also apply to fish caught. The results of the fish are very large and generate large amounts of money since being worked on by large companies with modern equipment. So it is not natural at all if fish are not subject to the obligation of zakat, which in this case can be analogous to mining goods, agricultural products, and others [3].
Zakat on assets is obligatory zakat on assets owned after reaching haul and nisab. Zakat is obligatory for every individual who has met the requirements to be obliged to issue zakat. The obligation to issue zakat is part of the pillars of Islam as the foundation of Islam whose obligations are always juxtaposed with prayer. Even in the Qur'an, the editor's call to pay zakat is often juxtaposed with the obligation to perform prayer, which shows that prayer and zakat are forbidden to be abandoned under any circumstances. In contrast to the fasting of Ramadan and Hajj in which there is an option not to do it for certain people.

The scholars of the school of fiqh have different editors in interpreting zakat. The Hanafi school defines it as the ownership of a certain part of a certain property for a certain party who has been determined by syari (Allah swt.) to expect His pleasure. The Malikiyah school defines Zakat as issuing a special portion of the property that has reached the nisab for those who are entitled to receive it, if it is perfect and reaches haul apart from mining, plants, and rikaz. The Syafi'iyah School stated that zakat is a name for something that is issued from property and body in a certain way. While the Hambali school considers zakat as an obligatory right in certain assets for certain groups [4].

\footnotetext{
* Corresponding author: fikriah.mimi@gmail.com
} 


\subsection{Urgency and nature of zakat distribution}

Classical scholars and contemporary scholars have agreed that zakat must be carried out by every Muslim who has property and has reached the nisab and haul [3]. The wisdom of zakat is fortifying wealth from the reach of criminals, helping the poor/people in need purify themselves from miserly and miserly diseases, and a form of gratitude for the blessings of wealth [4]. Zakat plays a role in the problem of the rich-poor difference, the problem of begging, the problem of envy and broken relationships with others, the problem of disaster, the problem of celibacy, and the problem of refugees [3]. Zakat is the most important means in overcoming the gap between rich and poor, and realizing solidarity or social security in Islam [4]. Qur'an said: [4:141]

"And give his due (zakat) when reaping the results"

In this verse, zakat is called a right because the portion / level that must be issued zakat from every asset that reaches the nisab is the right of another person who has been determined by Allah from someone who can afford it. So, the reluctance to pay zakat, indicates equality against taking the rights of others. Therefore, in the Qur'an it is also commanded to set aside a portion of wealth for zakat in order to purify and clean one's property [9:103].

The source of assets for Zakat includes mandatory Zakat for those who have completed nishab, complete property, and proper transportation (one year), rather than debt yield, which exceeds basic needs. The collected Zakat funds are then distributed to mustahik, the people who are entitled to receive it under Sharia law, including: Fakir, Poor, Amil, Mualaf, Riqab, Gharim, Sabilillah and IbnSabil [5].

There are some key notes that can be used as input to assess the progress of zakah institutions to increase the role and contribution of zakah in the national economy. First of all, the zakaah system is still voluntary, which is clearly visible in Article 12, paragraph 1, UU No. 38 1999. The zakaah system should be placed in a mandatory position so that zakah can play the role of an economic tool. Second, the Zakat system and mechanism are still under the jurisdiction of the Ministry of Religion. Therefore, Zakat should be used as a financial institution designated by the Minister of Finance or the government in the economic authority of the government. This can make Zakat an economic tool, so when philanthropy becomes a tool of economic policy, its effect will be more obvious [6].

\section{Methods}

\subsection{Types of research}

This research is in the form of literature research. The research was purposing to analyze the marine resources zakat on the perspective fiqh. The approach used is a qualitative normative approach in the form of detailed elaboration on marine zakat.

\subsection{Targets/subjects of research}

The research indicates the marine zakat as a target of research. With this, the study will focus on matters relating to fiqh analyze.

\subsection{Data analysis technique}

Data analysis in this research based on literature review that was conducted in an inductive descriptive manner.

\section{Result and discussion}

\subsection{Zakat of marine resources}

Economic growth in this modern era has led to the diversity of assets that can be obtained and has a very large productivity value. These potential assets do not mention the obligation of zakat in the Qur'an and hadith, but it does not mean that these assets are not an obligation to be issued zakat. The development of the times followed by the development of technology and science must also be accompanied by the development of thought in religious science/fiqh [7].

There are differences of opinion among scholars. However, the scholars of the four schools of thought agree that there are five types of assets that are obligatory to pay zakat, namely livestock (camels, cows, buffalo, goats/sheep), gold and silver (including paper money), trade, mining and found treasures, and agriculture. wheat, dates, grapes) [8].

The scholars of Fiqh differ on the ruling on items that are explored from the sea such as pearls, and Marjan and perfumes such as Amber which one piece can weigh up to 1000 mitsqal. According to Abu Hanifah and his friends and Hasan bin Salih and the Shia Zaidiyah school, nothing was imposed. Agreeing with that, Ibn Abbas narrated by Ibn Syaibah and others, said that Amber is not a treasure but is something produced by the sea and therefore is not subject to anything [3].

However, Ibn Abbas also once argued that if there is something in the amber, the zakat is $20 \%$. The mujtahid imams also differed in opinion, as narrated through Hasan bin Imara from Ibn Abbas from Umar Bin Khattab that amber and sea pearls are obligatory for zakat of $20 \%$. Another hadith narrated from Ibn Abbas also states that Ya'la bin Mina once wrote a letter to Umar about the law of images found in the coastal area, which Umar then asked his friends about, suggested that $20 \%$ of the zakat be withdrawn, which Umar replied to. the letter and ordered amber and all kinds of decorations taken from the sea to be issued zakat $20 \%$. But Umar is also reported to have another opinion about that which he replied to the letter to take zakat from Ambar and sea decorations of $10 \%$. The narrations originating from Umar above actually have not reached the level of authenticity. Some say the zakat is $20 \%$ like treasure $10 \%$ like agricultural products and $2.5 \%$ like dirhams and dinars [3].

Hasan bin Imara from Ibn Abbas from Umar bin Khattab said that amber and sea pearls must be paid zakat. And as has been narrated by the tabiin such as, 
and Hasan Basri and from Ibn Shihab Zuhri Abd Razak and Ibn Syaibah also narrated from Umar bin Abdul Aziz that he had collected zakat from amber, and added by the opinion of Abu Yusuf who stated that amber and any form of decoration that is removed from the sea, zakat is obligatory [3].

From the qiyas/analogy, goods released from the sea have the same position as ghanimah, which has already been legalized, and if it cannot be accepted, then at least it has the same position as mining goods that are removed from the earth because they are of the same nature. In this case, goods released from the sea are more reasonable if they are not exempt from the obligation of zakat and the amount of zakat is left to ijtihad and the decisions of experts. Marine products also apply to fish caught. The results of the fish are very large and generate large amounts of money since being worked on by large companies with modern equipment. So it is not natural at all if fish are not subject to the obligation of zakat, which in this case can be analogous to mining goods, agricultural products, and others. Abu Ubaid narrated from Yunus Bin Ubaid, "Umar once sent a letter to his officer in Oman so that he did not collect anything from fish that was less than 200 dirhams in value. If it is worth 200 dirhams, which is a large amount of money, then zakat must be collected." It was also narrated from the source of Ahmad. According to the Imamiyah school, the amount of zakat on fish is $20 \%$ because they view it as the same as ghanimah [3].

Imam Ahmad is of the opinion that goods produced from the sea such as fish, pearls, etc. are subject to zakat if the total price is the same as the price of the produce of the earth. This opinion was reinforced by Abu Yusuf from the Hanafi school, especially regarding rocks [9]. Basically, every asset that is obtained by a person, which has the potential to reach the nisab on the amount, must be paid zakat. The fulfillment of the obligation of zakat on every asset that reaches the nisab can be seen from the generality of the verses of the Qur'an in talking about infaq/zakat of assets from 'business results'. The results of operations (mimma kasabtum) are an indication or indication of all types and sources of income which are the result of business. So that the classification of zakat commodity goods contained in the hadith is basically an explanation of examples of the main sources of income that produced large incomes at the time of the Prophet, so that from the generality of this verse, it can be applied to other types of assets that have high potential for payment. zakat and the achievement of nisab\Qur'an says:

"O you who believe, spend (in the way of Allah) some of your good 'results' and some of what We bring out of the earth for you," [2:267]

Among the provisions of zakat is to clean one's property from the rights/parts of others that have been determined by Allah. Thus, it is inappropriate for a Muslim not to issue zakat from the 'business results' obtained which reach the nisab only because it is not classified in the zakat commodity at the time of the Prophet. Additionally, the verse also indicates zakat from the produce of the earth, which in this case can mean all goods and sustenance given by God that come from the earth, including ocean products. Qur'an said:
"Take zakat from some of their wealth, with that zakat you cleanse and purify them," [9:103]

Zakat can cleanse a person of stinginess and excessive love for material possessions and cultivate good qualities in the heart. The verse above is seen as very appropriate if we apply it to zakat on marine products, especially considering marine products now which have become commodities with high income value. Therefore, it further emphasizes that the law of issuing zakat on marine products is obligatory.

In a study, it was stated that zakat on marine products is the domain of ijtihadi, therefore an analysis is needed that can prove that marine products have provided sufficient profits to pay zakat. In this study with a sample in an area in Indonesia, proving that the fishing profession can also be subject to compulsory zakat if income from the sea reaches the nishab of zakat. In this case, of course, a large-scale exploration of marine products by a company gives more indication of its zakat obligation [10].

In addition to being recognized through the indications above, zakat on marine products is also required based on qiyas (analogy) which links something that does not have texts yet with something that already has texts because of an illat. In formulating the provisions of zakat on assets that are not mentioned in the hadith of the Prophet, it is done by applying qiyas. 'Illat which can be equated to zakat on marine products is the result/goods which is the result of the earth, which is found based on a search. In this case, it can be analogous to zakat on mining goods and rikaz (ancient relics), and it can also be analogous to zakat on plants which are also crops.

Zakat on marine products can also be said to be obligatory because the acquisition is no longer solely for consumption, but has been developed nowadays for very large productivity, both local trade and exports to various countries, whether carried out by individuals or controlled by companies. So that the obligation to pay zakat on marine products can also be applied through zakat money, gold and silver, or trade zakat.

Taking into account the number of 1.6 million fishermen, it is very important to extract zakaah from seafood, but in the past 10 years, as of February 3, 2017, the number of small-scale fishermen has decreased to 800,000 (Susi Pujiastuti, 2017). In 2016, it reached 125 trillion or 6.83 million tons, the highest output value in 5 years. Marine resources can exceed the income of farmers. Former Minister of Ocean Affairs and Fisheries Sharif Sisip Sutarjo revealed that the annual income of fishermen reached 52 million, which was higher than the income of farmers, which reached 20 million per year, and the income of fishermen was 26 million per year. year. In 2009, the fisheries sector grew by approximately $6 \%$, while the agricultural sector grew by $3.5 \%$ (Sharif Cicip Stutardjo, 2014). All types of zakah that have never been mentioned are zakah from marine resources. Note that the vast area of the Republic of Indonesia includes a land area of 1,910,931.32 square kilometers, and a sea area $=3,544,743.9$ square kilometers, two-thirds of which are marine resources. The collection of zakaah from fishermen is part of the legal investigation conducted by scholars, as a reference 
for decision-making, and is stipulated by the fishermen's zakah obligations [5].

\subsection{Terms and levels of spending zakat on marine products}

The condition for paying zakat is full ownership. Ownership is an innate nature that humans have from birth. In the Islamic perspective, obtaining it must be in a lawful way, not in a prohibited or unlawful way [11]. Wealth in the true sense belongs to Allah, and humans are only creatures who are given the mandate to use them in His way as vicegerents and representatives of Allah on earth and will be held accountable in the hereafter [12]. As a result of the fact that humans are only temporary owners of assets, these assets must be managed and used in accordance with the rules and limitations that have been outlined by Allah SWT. So that someone who has full possession of the property, is obliged to spend in the way of Allah, including through zakat.

Nisab according to jumhur is a condition that must be met in the issuance of zakat. The wealth that is subject to the obligation of zakat must reach the sensab agreed upon by the scholars, except for agricultural products, fruits, and precious metals. Abu Hanifa is of the opinion that a lot or a little, the results that grow from the soil must be paid zakat of ten percent. Likewise, the opinion of Ibn Abbas, Umar bin Abdul Aziz and others, that in ten bunches of vegetables that grow from the ground, one bunch of alms is obligatory. But Jumhur Ulama are of the opinion that nisablah is a provision that requires zakat on all wealth, whether it is wealth in the form of land or not [3].

The next requirement in the issuance of zakat is zakat is an excess of needs (in this case the intended need is a permanent need as a defense of life, so that the part of the property that will be issued zakat is not part of the property for that need), free from debt, and reaching haul (except in zakat on plants and minerals).

While the level / size of zakat expenditure, Ibn Taimiyah supports a varied ratio of zakat expenditure, which is due to the difference in the number of efforts from various jobs to produce. Theoretically, there are 4 kinds of percentages of zakat expenditure, namely $2.5 \%$ of income which is equated with gold and silver, $10 \%$ or $5 \%$ of land plants, livestock which is adjusted to the details of the amount, and $20 \%$ of assets found from the earth [13].

There are three opinions of scholars who oblige zakat on what is produced from the sea, as on the basis of qiyas from other zakat, including [14]:

a. The zakat of $1 / 5(20 \%)$ is analogized (qiyased) to ghanimah and minerals produced from the bowels of the earth, in this case some jurists are of the opinion that there is no nisab in it and there are those who think that it must reach the nisab by qiyas it on zakat. gold [3].

b. The zakat of $1 / 10(10 \%)$ is analogous to agricultural zakat. For the expenditure of zakat, the yield from plants and fruits, the nisab is $653 \mathrm{~kg}$ [4].

c. The $2.5 \%$ zakat is analogous to trade zakat. In this case, trade zakat is equated with zakat on gold and silver. The nisab for gold and silver is 20 dinars (gold) and 200 dirhams (silver). Based on the opinion of Yusuf Qardawi, 20 dinars is equivalent to 85 grams of gold. And 200 dirhams are equivalent to 595 grams of silver. When this number has been reached, the zakat that must be issued is $2.5 \%$ of the nisab. There are also differences in the level of zakat on mining goods, some are of the opinion $20 \%$ and some are of the opinion $2.5 \%$ [3].

The amount of zakat will increase if the level of difficulty decreases. On the other hand, the amount of zakat will decrease if the effort and costs increase, as in the zakat of agricultural products irrigated with rain water is different from that irrigated with irrigation [3]. By considering the determination of zakat on marine products as a source of zakat by the government, the community (especially coastal communities) who are not financially capable can be helped from the existence of marine zakat sources which are known that marine resources with very large amounts have the potential to be issued zakat [7]. Strategic solutions that are prioritized in zakat associations are on the System, External, and Internal aspects. Thus, fighting for zakat through the legislative and executive channels becomes of high urgency [15].

\section{Conclusion}

There is also a need for seafood zakah based on qiyas (analogs), which connects things that have not yet been text with things that already have text due to illat. When formulating zakah clauses for assets not mentioned in the hadith of the prophet, it was done through the application of qiyas. The obligation to pay for seafood Zakat can also be fulfilled through Zakat currency, gold and silver or trade Zakat. The collection of zakaah from fishermen is part of the legal investigation conducted by scholars, as a reference for decision-making, and is stipulated by the fishermen's zakah obligation.

Acknowledgment: Sincere thanks are due to the Research Center for Marince Sciences and Fisheries, Universitas Syiah Kuala for their effort in organizing the $10^{\text {th }}$ ICMR in conjunction with the $2^{\text {nd }}$ INSAEF. The writing of this manuscript is supported by the Matching Fund - Kedaireka funded by the Ministry of Education, Culture, Research, and Technology Indonesia awarded to the Research Center for Marine Sciences and Fisheries, Universitas Syiah Kuala.

\section{References}

1. R. Ritonga, Figh Muamalah (Edaran Kalam, Kuala Lumpur, 1999)

2. M. U. Capra, Islam Dan Tantangan Ekonomi (Gema Insani, Jakarta, 2000)

3. Y. Qardawi, Hukum Zakat (Pusataka Litera Antar Nusa Bogor Baru, Bogor, 1988)

4. W. Az-Zuhaili, Fiqih Islam Wa Adillatuhu (Gema Insani, Jakarta, 2011)

5. A. Muhasim, H. Hirsanuddin, and H. Ul Haq, J. Lib. Amd Int. Aff. 5, (2019) 
6. M. E. Nasution, in Potential Socio Islam. Financ. Institutions Islam. Financ. Syst. (2007), p. 5

7. D. S. Riwanto, Int. J. Zakat 2, 29 (2017)

8. A. Asnaini, Zakat Produktif (Pustaka Pelajar, Yogyakarta, 2008)

9. Z. dan W. Proyek Peningkatan Sarana Keagamaan Islam, Pedoman Zakat 9 Seri (Proyek Peningkatan Sarana Keagamaan Islam, Zakat dan Wakaf, Jakarta, 1998)

10. R. Firdausiyah, Analysis of Fishermen's Zakat from Sea Catch (Case Study of Tambak Village, Tambak District, Bawean) (State Islamic University of Sunan Ampel, Surabaya, 2020)

11. M. Alim, Asas-Asas Negara Hukum Modern Dalam Islam; Kajian Komprehensif Islam Dan Ketatanegaraan (LkiS, Yogyakarta, 2010)

12. R. Rozalinda, Ekonomi Islam (Rajawali Pers, Jakarta, 2014)

13. M. S. Ibrahim, Int. J. Business, Econ. Law 5, 49 (2014)

14. M. A. Hasan, Zakat Dan Infak: Salah Satu Solusi Mengatasi Problema Sosial Di Indonesia (Kencana, Jakarta, 2008)

15. A. Ascarya and D. Yumanita, Work. Pap. 9, (2018) 